International Research Journal of Management, IT \& Social Sciences
Available online at https://sloap.org/journals/index.php/irjmis/
Vol. 5 No. 6, November 2018, pages: 17 25
ISSN: 2395-7492
https://doi.org/10.21744/irjmis.v5n6.305

\title{
The Second Concert of Powers: Managing US-China Competition on the Korean Peninsula Conflict in Terms of International Communication Perspective
}

\author{
I.G.A.A.G. Dewi Sucitawathi Pinatih ${ }^{a}$ \\ Nuning Indah Pratiwi ${ }^{\text {b }}$ \\ Putri Ekaresty $^{c}$
}

Article history:

Received: 20 July 2018

Accepted: 30 September 2018

Published: 9 October 2018

Keywords:

Conflict managers;

Democratizers;

Diplomacy;

International communication

perspective

Six-party talks;

\begin{abstract}
The conflict in the Korean peninsula is an issue that becoming a most major concern in the region other than the case of the South China Sea. Struggle for influence between the United States and China give new nuances in terms of supremacy competition and political status as a superpower. The war that occurred between two Koreans ensure that the balance of power will become the most dominant issue of the United States and China put forward in the future. Profits will be more felt by those who are disputing (South Korea and North Korea), compared to the United States and China. Paradigm to see that the conditions of the Cold War will happen again in the East Asia region should focus on the dominant form of economic compensation provided by each country (US and China). Conflict, therefore, require efforts to fight the influence by managing it well, so that it will give more benefits than losses for all affected countries. In this case, a diplomatic approach is needed in the form of conflict management communication to prevent armed contact between the two countries to fight for influence on the Korean peninsula.
\end{abstract}

2395-7492@ Copyright 2018. The Author. This is an open-access article under the CC BY-SA license (https://creativecommons.org/licenses/by-sa/4.0/) All rights reserved.

Author correspondence:

I.G.A.A.G. Dewi Sucitawathi Pinatih,

University of National Education, Indonesia

Email address:iga_dewi@undiknas.ac.id

\section{Introduction}

One of the real legacies of the competition of the two main forces in Cold War-era international politics was the conflict on the Korean Peninsula. The outbreak of civil war on the Korean Peninsula in the 1950s was the result of competition for influence between the US and the Soviet Union, where the struggle and expansion of influence (sphere

${ }^{a}$ University of National Education, Indonesia

${ }^{\mathrm{b}}$ University of National Education, Indonesia

${ }^{c}$ University of National Education, Indonesia 
of influence) could be a benchmark for how the influence of the Cold War was still very much felt between the two Koreas up to now. The two major countries (the US and the Soviet Union) divided Korea based on ideological similarities, even though each satellite country was not located in the same geographical area as the orbit state.

Gill (2011), the collapse of the Soviet Union's political superpower against the US, the tendency of the Cold War conditions have been increasingly felt, especially with China's presence as a new US counterpart, not only in the economic field but also in politics. Influence competition in the East Asian region is dominant, due to an increase in the militarization of China, in anticipation of the presence of US global hegemony. In the spring of March-April 2010, the Chinese Navy (PLAN) known as the East, North, and South Sea Fleet held joint exercises in the South China Sea bypassing Okinawa and Taiwan. Actions to hold joint patrols and exercises certainly interpret that Taiwan and the South China Sea are part of Chinese sovereignty.

Kim (2010), the incident received a strong response from the US, Japan, Taiwan, and Southeast Asian countries. In addition, the conditions that triggered the US presence to act were related to the allied state of South Korea when March 26, 2010, the South Korean Navy warship "Cheonan" was sunk, causing 50 sailors to die, and also November 23, 2010, when North Korea opened fire on Yeonpyeong Island. The need to maintain security stability in the East Asia region is the main reason the US is increasingly closer to political security cooperation not only with allies like South Korea when it gets attacks but also begins to increase military, diplomatic and economic cooperation with several Southeast Asian countries.

With Taiwan cooperation was carried out in the form of arms deliveries to protect the internal security of its territory, and with Japan, it still provided space for the US to place military bases in Okinawa, although there were plans to relocate due to some refusal from civilians. The Chinese side saw a network of political cooperation increasingly expanded by the US by expanding into Southeast Asia, East Asia with Taiwan and Japan as a counter to its existence (China). The conflict between the US and China does not just happen, in the sense that conflict is more likely to occur when the Cold War ends.

US victory automatically causes the international political system to follow the rules of a single hegemon, especially in applying democratic principles. The end of the Cold War, several issues related to human rights violations, trade conflicts, the adoption of democratic values, and the sale of weapons to Taiwan, were the trigger for the initial disharmony of US-China relations. The conflict became increasingly serious when China became a country that could no longer be underestimated by the US. Its economic rise and extraordinary military budget are becoming a threat to US influence not only on a global but also regional scale in the East Asia region (Miall, et al., 1999, Ifeanyichukwu, 2018).

The US and China see their position in competitive conditions such as when the Cold War occurred. The difference lies in the degree of insignificant influence on the part of China to expand influence outside of East Asia which is regionally and globally controlled by the US. The Cold War when the US and Soviet Union controlled the international system, tended to form a coalition by providing a security umbrella in the field of security (security) or high politics issue, both in the placement of military bases and security cooperation in the form of alliances (NATO or Warsaw Pact). While the new paradigm that is formed from the existence of the US and China is a competition of influence that is not only based on hard power (militarization) but also with the soft power (economy) that each country already has.

Qian \& Wu (2009), when the US struggled for influence with the Soviet Union, the tendency was that the United States had complete military and economic stability, while the Soviet Union tended to be only established in military terms, while weaker in economic conditions. Not infrequently many say that one of the factors of the collapse of the Soviet Union was the economic conditions that ultimately led to the existence of a fractional state such as Russia, Ukraine, Georgia, and Estonia. Now what happens is the struggle for influence between two balanced forces, where the US military is strong and the economy is strong, China can be said to be a strong military and its economy is also strong. The antagonism of the conditions of the two countries can be interpreted through two things, namely the existence of China and the containment policy that is re-implemented by the US.

Ki-Moon (2006), the first thing was clearly caused by an increase in China's military budget and shifted Japan into the world's most powerful economy, no. 2 after the US. In terms of international relations, China saw the weakness of the US in responding to several sensitive issues such as the Korean Peninsula and Iran's nuclear non-proliferation problems. Structural changes clearly occur in international politics, due to a response from China to be able to replace the US position into a single hegemon that is more responsible for handling important issues for the creation of world peace. The conflict on the Korean Peninsula is seen as a clear picture of how the US and China try to maintain political supremacy by attracting several key allies through the economic compensation provided. 
Geopolitically the existence of the Korean Peninsula is considered a stepping stone to attack both from and to Japan. It is clearly known that Japan is the most important ally for the US in the East Asia region in particular. Since the war in the 1950s, the conflict between the two Koreas has tended to lead to the goal that there is no desire to give the opponent the slightest advantage. Even both parties (South Korea and North Korea) consider that the border is considered a dividing line between countries. At that time the United States was supported by the United Nations in dealing with the Korean War, at which time China was an ally of the Soviet Union and felt threatened and eventually participated in the war.

China said that it would not claim territory beyond traditional power, and only wanted to seek peace with neighboring countries. When the war ended in 1953, China's influence was politically very strong in North Korea despite not placing its troops. In 1961 China and the Soviet Union signed a security cooperation agreement with North Korea, and finally, a split broke out in Sino-Soviet relations and gave North Korea the advantage of playing with both parties in conflict. After the Soviet Union collapsed, China became the dominant single player influencing North Korea to date.

It is often said that the struggle for influence in the East Asia region from the US and China, as a natural thing due to the relatively equal power balance between the two countries. But despite the struggle for influence over a particular regional region, conditions of interdependence tend to greatly influence the US and China on a number of international issues. It is also said that China still has the disadvantage of balancing power as a hegemon like the US. Therefore, China needs several periods of time to be able to achieve the same conditions or equal to the US.

Ross (2005), seeing the traditional threat to state stability no longer dominates relations between countries, of course, non-traditional threats will become China's main consideration when later it can become equivalent to the US, where the two countries (US-China) must cooperate with each other. It is indeed early enough to say that East Asia is in the same condition as the Cold War era. If reviewed further, the trend that occurs is post-European War conditions, which results in conditions known as "concert of powers". The Concert of Powers is clearly more capable of interpreting US-China relations to respond to traditional and non-traditional issues.

Salisbury (2010), a little pessimistic to hope that the conflict will lead to a war between the US and China because the US and China tend to prioritize cooperation in the form of negotiations to respond to some crucial issues. At present the Obama administration is encouraged to be more proactive in addressing the North Korean nuclear crisis, emphasizing the issue of "containment" strategies and "comprehensive" approaches through international forums such as the six-party talks. When the two countries are in a state of cooperation, it is very unlikely that each country will prioritize competition that is at great risk, both in terms of morals and economics. The issue of the Korean Peninsula has indeed become the main frontier of the Cold War era in Asia (similar to Berlin in Germany), but the two countries are competing in influencing influence in several other regional countries based solely on conditions to ward off or as deterrence against their opponents.

War may not occur between the US and China, but the security dilemma will predominantly influence the relations between the two countries, both when working together. For the US, China is seen as an expansionist country in terms of military and economic matters. South Korea became a US ally with the hope that US supremacy would continue to be recognized in East Asia even without North Korea's support. Circumstances on the Korean Peninsula formally remain in a state of war, but only in the form of small-scale battles such as in Yeonpyeong, and will certainly greatly influence the US and China in placing their supremacy of political power.

\section{Materials and Methods}

This study uses qualitative methods and the data sources used are secondary data. Secondary data is data obtained from library sources such as books, literature, documents, and other supporting sources related to this research. The type of data in this study is qualitative data which is data that is not in the form of numbers but is information related to the problem to be studied. In this study, the qualitative data used was a discussion of the struggle for influence between China and the United States in the Korean peninsula conflict. The theory used is a theory in communication science. Conflict management communication theory is a theory that explains the balance of power carried out by China and the United States in the case of the Korean peninsula. In theory, it also explains the concept of conflict managers and democratizers. In addition, in theory, the issue of diplomacy, reconciliation, and balance of power in the East Asia region also was mentioned.

Pinatih, I. D. S., Pratiwi, N. I., \& Ekaresty, P. (2018). The second concert of powers: managing US-China competition on the Korean peninsula conflict in terms of international communication perspective. International Research Journal of Management, IT and Social Sciences, 5(6), 17-25. https://doi.org/10.21744/irjmis.v5n6.305 


\section{Results and Discussions}

The success of big powers in carrying out their foreign policy can be reviewed in two ways, first when they (great powers) know to secure the vital interests of their country, and know how to organize a competition to reduce tension, regional instability, and war. When a strong country plays a dominant role in an area, what will happen is definitely the condition of hegemony, the balance of power, European "concert" system, collective security and a pluralistic security community. US foreign policy was conditioned according to the demands of the external environment when it succeeded in becoming a superpower in the 20th century, through policies taken against Germany and the Soviet Union. Securing US interests requires war, and the emergence of other countries' participation in armed contact (related to certain issues, such as human rights), nuclear crisis, and regional conflicts in periphery countries.

Shulong \& Xinzhu (2008), the end of the Cold War, became a clear picture to see that the orientation of countries, in the end, was more dominant with regard to domestic development problems. Regional, bilateral, multilateral, trilateral cooperation increasingly responds to issues related to economic problems as a result of the costs of participation in World War II. The country began to emerge which was almost able to compete with the US in the economic field, namely China. China's economic conditions are increasingly stretched, coupled with complementization in terms of its militarization. The Chinese government's annual military budget has increased and has led to a response or prejudice that China is designing a strategy to be able to compete with the United States in launching political influence.

Soo-Ho (2010), the existence of China, which is growing rapidly in the economy and the military, creates huge challenges for the status quo in East Asia, especially for US influence and the old economic forces like Japan. Seeing the reference to the success of the great powers to be able to maintain the stability of world peace and regionalism, in particular, the question arises. Is China's rapid military economic development a challenge for US existence, and must be anticipated with the risk of instability in the East Asia region. Conflict on the Korean Peninsula can be the basis for talking about how the existence of the old US forces and the new Chinese forces consolidate their policies to ensure that competition will not harm other parties or neighboring countries, which greatly hopes for regional security responsibilities.

The escalation of the US and China conflicts further added obstacles to resolving the two Korean problems. First, because the US and Chinese conflicts will only lead to utopia or mere shadow in dealing with North Korea regarding the management and resolution of its nuclear power enrichment activities. North Korea's nuclear problems are not only a form of "balance of power", but are more clearly seen in instability in the East Asia region, due to the possession of nuclear weapons that are used not for peaceful purposes, but as if to show that North Korea deserves to be considered a strong country in the international political system with China.

Addressing issues since 2000 was carried out bilaterally, both between the two Koreas and the US with North Korea. Since 2003, six-party talks (multilateral) have been formed to achieve a peaceful resolution. The existence of six-party talks as a major reflection of the concert of powers between the US and China, with the support of other countries that aim not only to hope to achieve "resolution or agreement" related to North Korea's nuclear activities but at least "manage" the issue. The US position is not very favorable on the Korean Peninsula issue, because China uses the issue as a card to threaten the US in the East Asia region. At least the second issue of Korea can guarantee that political power in Taiwan and the South China Sea is not disturbed, this is because the important "card" is in Chinese hands.

Second, the deterioration of the US and China will further complicate the unification of the two Koreas. In terms of unification, each party (US and China) does not want that the unification of the two Koreas will eventually fall into the hands of one party. Dominant concerns emerged from Japan, regarding his fear that the unification of Korea would fall into Chinese influence. Unification as the ultimate goal of the Korean conflict must be motivated by a consensus strategy from the US and China as key players. Why is said to be a key player? Because each Korea feels there is a security guarantee provided by the US and China in East Asia. North Korea for example, if it does not get Chinese blessing and support, it is impossible to dare to proclaim a strong military state despite the weak economic conditions of its country. China actually does not want North Korea to be a nuclear state but wants to influence its government regime as a counter against the dominant US presence in East Asia. Its nuclear activity is not due to Chinese intervention, but rather to "exploiting" North Korea's ego as an instrument against the US.

The unification of the two Koreas, should not only be seen as a calculation of profit and loss in international relations, but there must be a "trust" trust later from the US and China as a commitment to maintain the stability of a regional region. South Korea as the country that gets the most impact from the US and Chinese competition must make choices, namely the security and sustainability of US-China relations in the future. For South Korea, a security alliance 
with the US is the most important asset for the country. Trust in the US is more likely to be caused by historical factors during the Cold War. Reaching an agreement and implementing it in the form of concrete actions do require the trust of each party.

\section{Communication approach: conflict managers or democratizers?}

The challenges here are far greater on the US side. The strategy to utilize conflict so that it can be an advantage for all parties is to realize that the vital interests of the state must be a top priority. Therefore the US must be able to manage conflict through various political strategies against China without armed contact and can minimize regional instability in East Asia. China was not the same competitor as Germany in World War I, and the Soviet Union in the Cold War. Therefore the US must be able to see the characteristics of China as a challenge rather than an obstacle, which can be regulated through a strategy to achieve political goals. While China must play an active role in international forums in dealing with international issues, so there will be no impression that China has historically rarely played a role as a mediator because it emphasizes the principles of non-intervention, neutrality, sovereignty, and territorial integrity of the country.

The US must be able to see itself as a "conflict manager" or "democratizers" especially addressing the issue of the Korean Peninsula. Conflict management as an effort to stem violent conflict must be implemented by the US in response to the political policies adopted by China. As a great power, the US must be able to be in a position as a "conflict manager" in the second case of Korea, and not as "democratizers". The purpose of a conflict manager is "peace", while democratizers are justice. Associated with the existence of six-party talks that are expected not only to achieve a "resolution" but at least there is an attempt to "manage" the Korean conflict. So it is suitable if the US conditions foreign policy for long-term reconciliation in the East Asia region.

\begin{tabular}{|l|l|l|}
\hline Negative Peace & \multicolumn{2}{|c|}{ Positive Peace } \\
\hline Absence of violence & $\begin{array}{l}\text { Truth/acknowledgment } \\
\text { Reparation/rehabilitation } \\
\text { Punishment/pardon }\end{array}$ & Long-term reconciliation \\
\hline
\end{tabular}

Figure 1. From negative to positive peace, via justice

Sung-Han (2008), the definition of "reconciliation" one of which means the restoration of kinship. In the case of the Korean Peninsula, the US must see that their aim is the long-term reconciliation of the two Koreas. Justice cannot be expected from North Korea, because the authoritarian regime of the government is very difficult to change the political ideology of the country. Coercion of a nation's ideology will further worsen the regional stability of the East Asian region and hinder the achievement of peace. If the US forces to apply the principle of democracy to North Korea (democratizers), then China will immediately respond quickly to interventions against ideology and possibly even North Korean sovereignty. So it's better to remain a "conflict manager" by ensuring that national interests can still be achieved in East Asia.

Reconciliation does not mean that the US must reduce influence in East Asia, but wait for the right time to strategize by cooperating with North Korea. Currently, North Korea is preoccupied with domestic affairs, related to the issue of government change from Kim Jong IL to Kim Jong UN. North Korea often makes unexpected actions, for example against South Korea (Cheonan and Yeonpyeong). The change of leadership is expected to be able to bring about changes in North Korea's domestic politics. Conditions to focus more on economic problems than politics are expected to be prioritized later. Of course, the relationship with the US as a dominant global political actor will be further enhanced.

North Korea often takes actions that have a negative impact on the East Asia region with the aim of attracting US attention in particular. Personified as a child who intentionally acts "mischievous" in order to get attention from his parents, this is the same as that carried out by North Korea. In addition, the response to the US nuclear threat was

Pinatih, I. D. S., Pratiwi, N. I., \& Ekaresty, P. (2018). The second concert of powers: managing US-China competition on the Korean peninsula conflict in terms of international communication perspective. International Research Journal of Management, IT and Social Sciences, 5(6), 17-25. https://doi.org/10.21744/irjmis.v5n6.305 
responded differently by North Korea according to its shape, sharpness, and level. They want that existence to be recognized internationally, and not only always compared to the economic power of South Korea that is very far away. Regarding the nuclear issue, the US does not emphasize that North Korea does not have nuclear weapons, but focuses on the problem of nuclear non-proliferation.

As with other countries such as Russia, the country has nuclear weapons but since the Soviet Union collapsed, Russia has not made the nuclear issue to seek world attention to it, although it is still symbolically communist in ideology. Unification is Korea's second internal problem according to the Chinese side and does not require intervention from other parties such as the US. China will approve when later the two Koreas unite, provided North Korea is not lost. And the US military force is no longer allowed to be on the Yalu River because it is considered a threat to influence the two Koreas and spy on China in East Asia.

The desire to unite does exist from outside Korea, but the problem tends to be in South Korea and North Korea until now. Historical facts clearly have a big influence to separate the two regions that have the same cultural background. See what happened in Europe, conditions on the Korean Peninsula exactly but not the same as the Berlin Wall in Germany. After Germany experienced unification, each individual community felt differences from one another. They still feel separated as West Germans and East Germans. And ironically, there is prejudice from a West German society that East Germany is only a burden because it joins in very bad economic conditions. Same is seen in the case of the Korean Peninsula later.

But it cannot be predicted with certainty, because there will be an immediate succession of dynastic leadership in North Korea. For North Korea national security is not so important compared to the security of the ruling regime. In a sense, political instability (low public support for the government), social, economic state, is far more dangerous than threats from South Korea and the US. It is important to see that the Korean Peninsula can be a guide to how two great powers balance their strengths, by consolidating policies in the six-party talk's forum. The existence of six-party talks is an "engagement strategy" which is based on a conceptual framework for solving problems on the Korean Peninsula through dialogue. The forum is a means especially for China, which is concerned that North Korea's nuclear activities will trigger other countries in East Asia such as Japan, South Korea, and Taiwan to take part in possessing nuclear weapons. And of course, it will make it difficult for China to guarantee peace, stability, security, sustainability of the East Asia region in the future.

In addition, China wants to avoid the burden of economic and diplomatic costs if the change of regime Kim Jong Il will bring North Korea closer to the US, and cause an explosion of refugees to mainland China. So it is important for the US and China to work together in dealing with the second issue of Korea. In addition to security purposes, credibility as a major country is at stake in dealing with the issue. The balance of forces will be better able to guarantee that each country knows the consequences if one party attacks one another. The state of countries in an anarchic world system is naturally described as a state of distrust with one another.

But it does not open the possibility to join in a cooperation forum to ensure that there is an agreement in the form of bilateral, trilateral, multilateral agreements that are able to become pioneers of the United States to achieve international stability. The current trends will form a new paradigm in the Cold War era of the 1940s. At this time, the struggle for influence does not need to carry the risk of war between countries. But it's just a kind of conflict that can't escalate big. National interests can continue to be prioritized, provided that each major country realizes their condition as a defense motor for other regions from traditional and non-traditional security threats.

\section{Conclusion}

The power competition between the US and China must be seen as a balance of power efforts in the East Asia region. Need to say that the Korean Peninsula conflict is indeed beneficial. This is because East Asia will again see that their solidarity (countries) is not large, and requires an awareness that cooperation needs to be improved. Look at Japan which tends to be in alliance with the US, South Korea-US, Taiwan-US, North Korea-China. Each country has not been able to show identification as a community that inhabits the same geographical area. The influence coming from the US is very dominant in forming a pattern of cooperative relations in East Asia.

The Cold War which was not thick in militaristic nuances of the US and China could become a new paradigm in seeing the phenomenon that occurred. The Cold War used to be unbalanced between the US and the Soviet Union because one party did not have enough economic stability to rival the liberal US political ideology. Now there is a Chinese that is ideologically opposed, but economically almost able to balance the US. The second condition of Korea, 
if it is in the process of unification, then the US must be able to become a "conflict manager" not "democratizers". The role of a conflict manager prioritizes peace, by respecting the political ideology of other countries.

One way to manage the US and Chinese conflicts related to the Korean Peninsula issue by involving them in the six-party talks forum. Forum effectiveness can be a hope to regulate and influence Pyongyang's policies which are very contradictory to the principles of world peace. The US and China do not want to get lost by making contact to fight for political supremacy in East Asia. Therefore, indeed the conditions created are a balance of power, which will surely create a security dilemma in East Asia. Security guarantees remain provided by the US and China to allies in East Asia, through the placement of military bases and joint military training. Peace in the East Asia region today is peace in the balance of US and Chinese influence.

Conflict of interest statement and funding sources

The authors declared that they have no competing interest. The study was financed by personal funding.

Statement of authorship

The authors have a responsibility for the conception and design of the study. The authors have approved the final article.

\section{Acknowledgments}

The authors thank all the parties who those support in completing the present article.

Pinatih, I. D. S., Pratiwi, N. I., \& Ekaresty, P. (2018). The second concert of powers: managing US-China competition on the Korean peninsula conflict in terms of international communication perspective. International Research Journal of Management, IT and Social Sciences, 5(6), 17-25. https://doi.org/10.21744/irjmis.v5n6.305 


\section{References}

Gill, B. (2011). China's North Korea Policy. Special Report, 283, 8.

Ifeanyichukwu, C. (2018). The Role of Sensory Marketing in Achieving Customer Patronage in Fast Food Restaurants in Awka.

Kim, S. S. (2010). North Korea's nuclear strategy and the interface between international and domestic politics. Asian Perspective, 49-85.

Ki-Moon, B. (2006). For permanent peace: beyond the nuclear challenge and the Cold War. Harvard International Review, 28(2), 24.

Miall, H., Ramsbotham, O., \& Woodhouse, T. (1999). Contemporary conflict resolution: The prevention, management and transformation of deadly conflict. Cambridge: Polity.

Qian, C., \& Wu, X. (2009). The Art of China's Mediation during the Nuclear Crisis on the Korean Peninsula. Asian Affairs: An American Review, 36(2), 79-96.

Ross, R. S. (2005). A Realist Policy for Managing US-China Competition. Policy Analysis Brief, 5.

Salisbury, D. (2010). US Policy Toward the Korean Peninsula. Arms Control Today, 40(6), 7.

Shulong, C., \& Xinzhu, L. (2008). The six party talks: A Chinese perspective. Asian Perspective, 29-43.

Soo-Ho, L. (2010). US-China Conflict: Impact on the Korean Peninsula. SERI Quarterly, 3(4).

Sung-Han, K. (2008). Searching for a Northeast Asian Peace and Security Mechanism. Asian Perspective, 127-156. 


\section{Biography of Authors}

\begin{tabular}{|c|c|}
\hline & $\begin{array}{l}\text { I.G.A.A.G. Dewi Sucitawathi Pinatih graduated her bachelor degree at the international } \\
\text { relation studies program, Jayabaya University, Jakarta. She finished her master degree } \\
\text { program in the international relations, University of Katolik Parahyangan, Bandung. She } \\
\text { currently works as a permanent lecturer at the University of National Education } \\
\text { (Undiknas), Faculty of Law and Social Sciences. She interested in the field study } \\
\text { included an introduction to political science, Indonesian political systems, political } \\
\text { theory, and political sociology. } \\
\text { Email:iga_dewi@undiknas.ac.id }\end{array}$ \\
\hline & $\begin{array}{l}\text { Nuning Indah Pratiwi graduated her bachelor degree in the international relation studies } \\
\text { program, University of Katolik Indonesia, Jakarta. She finished her master degree in } \\
\text { communication studies program, Padjajaran University, Bandung. She currently works } \\
\text { as a permanent lecturer at the University of National Education (Undiknas), Faculty of } \\
\text { Law and Social Sciences. She interested in the field study included communication } \\
\text { theory, business communication, communication management, and international } \\
\text { communication. } \\
\text { Email: nuningindahpratiwi@undiknas.ac.id }\end{array}$ \\
\hline & $\begin{array}{l}\text { Putri Ekaresty graduated her bachelor degree in communication studies program, } \\
\text { University of National Education, Denpasar. She finished her master degree in } \\
\text { communication science studies program, Padjajaran University, Bandung. She currently } \\
\text { works as a permanent lecturer at University of National Education (Undiknas) in the } \\
\text { Faculty of Law and Social Sciences. She interested in the field study included an } \\
\text { introduction to communication science, sociology of communication, public speaking, } \\
\text { and basic journalism. } \\
\text { Email: ekarestyhaes@undiknas.ac.id }\end{array}$ \\
\hline
\end{tabular}

Pinatih, I. D. S., Pratiwi, N. I., \& Ekaresty, P. (2018). The second concert of powers: managing US-China competition on the Korean peninsula conflict in terms of international communication perspective. International Research Journal of Management, IT and Social Sciences, 5(6), 17-25. https://doi.org/10.21744/irjmis.v5n6.305 